\title{
Phosphorylation of the Termini of Cauliflower mosaic virus Precapsid Protein Is Important for Productive Infection
}

\author{
Julie Champagne, Marie-Eve Laliberté-Gagné, and Denis Leclerc \\ Centre de Recherche en Infectiologie, CHUQ, Pavillon CHUL, Québec, G1V 4G2, Canada \\ Submitted 5 November 2006. Accepted 7 February 2007.
}

\begin{abstract}
Cauliflower mosaic virus (CaMV) coat protein precursor (pre-CP) has 489 amino acids (p57) and is processed by the viral proteinase into three major forms: p44, p39, and p37. The $\mathrm{N}$ - and $\mathrm{C}$-terminal extensions of pre- $\mathrm{CP}$ are released during maturation by the virus-encoded proteinase. We showed that these extensions are phosphorylated at several sites by host casein kinase II (CKII). We have identified the phosphorylated amino acids using an in vitro phosphorylation assay and tested the effect of mutation of these sites on viral infectivity. Mutation of serines S66, S68, and S72 to alanine in the $\mathbf{N}$-terminal extension abolished phosphorylation of the protein in vitro. Also, mutation of all $S$ and $T$ residues in the $C$-terminus ( 450 to 489 ) made this region insensitive to CKII. Amino acid substitutions also were introduced into a full-length infectious clone of CaMV. Mutated forms of the virus with S66, S68, and S72 substituted with A or D showed a delay in symptom development and affected the infectivity of the virus. However, a mutant with an A substitution of all the $S$ and $T$ residues of the $C$-terminal extension of CP was not infectious. These results suggest that phosphorylation of the $\mathrm{N}$ - and $\mathrm{C}$-termini of $\mathrm{CaMV}$ pre-CP plays an important role in the initiation of viral infection.
\end{abstract}

Cauliflower mosaic virus (CaMV), the type member of the Caulimoviridae family (Hohn and Fütterer 1997), possesses a circular double-stranded DNA genome of approximately $8 \mathrm{~kb}$ encoding eight open reading frames (ORFs). The CaMV coat protein (CP) is synthesized from ORF IV as a 489-amino-acid precursor (pre-CP, $57 \mathrm{kDa}$ ), which is processed by the virusencoded protease (pV) into three CP subspecies: $\mathrm{p} 44, \mathrm{p} 39$, and p37 (Torruella et al. 1989). The CP that forms the virion is found mostly in its fully processed mature form (p37) (Fig. 1). The $\mathrm{N}$ - and C-terminal extensions of CaMV pre-CP are released by the virally encoded protease and an unknown host-encoded protease (Karsies et al. 2001; Torruella et al. 1989).

CaMV CP is involved in assembly (Chapdelaine and Hohn 1998), packaging of the viral RNA (Guerra-Peraza et al. 2000), and delivery of the viral genome to the nucleus (Karsies et al. 2002; Leclerc et al. 1999). The N-terminal domain (amino acid residues 1 to 76 ) and the $\mathrm{C}$-terminal region (residues 450 to 489) of CaMV pre-CP contain a large number of acidic residues. Both terminal domains are removed by cleavage to form the processed CaMV CP (Torruella et al. 1989). The Cterminal extension was shown to inhibit the interaction of $\mathrm{CP}$ with the leader of the viral pregenomic RNA (Guerra-Peraza et

Corresponding author: Denis Leclerc; Telephone: +1-418-654-2705; Fax: +1-418-654-2715; E-mail: denis.leclerc@ crchul.ulaval.ca al. 2000). The N-terminal extension was shown to inhibit nuclear targeting of $\mathrm{CP}$ to the nucleus, and it has been proposed that this domain allows retention of pre-CP in the cytoplasm for virus assembly and packaging (Champagne et al. 2004; Karsies et al. 2002; Leclerc et al. 1999). We recently showed in planta that the N-terminal extension was found associated with viral particles in small inclusion bodies located close to the presumed plasma membrane (Champagne et al. 2004).

The $\mathrm{N}$ - and C-terminal extensions contain instability domains in the CP precursor, and are sufficient to direct degradation of a heterologous protein-chloramphenicol acetyl transferase (Karsies et al. 2001). In addition, the abundance of $S$ and $\mathrm{T}$ residues in both extensions suggests that they also could harbor phosphorylation targets.

Several animal and plant viral proteins are modified by protein kinase-mediated phosphorylation, and evidence that this modification has implications for virus infection is increasing. Serine or threonine kinases involved in phosphorylation of CaMV have been shown to be associated with purified virus particles (Geldreich et al. 1988; Menissier-de Murcia et al. 1986). The $\mathrm{p} 44$ form of CaMV CP has been shown to be phosphorylated in vivo by the host casein kinase II (CKII)-like protein kinase (Martinez-Izquierdo and Hohn 1987). Phosphorylation of viral CP (p44) by CKII was mapped to S82, S86, and S88 and shown to be important for viral infectivity (Chapdelaine et al. 2002). These phosphorylated residues are present in the partially processed $\mathrm{CP}$ often found in the mature virion. The N-terminus of p44 starts at position 77 of pre-CP (MartinezIzquierdo and Hohn 1987). It was shown that the p39 and p37 forms are further processed beyond amino acid 88 because these forms are not phosphorylated by CKII (Chapdelaine et al. 2002). The latter study also provided evidence for additional phosphorylation sites in the $\mathrm{N}$ - and $\mathrm{C}$-terminal extensions of pre-CP (Chapdelaine et al. 2002).

The aim of this work was to map the phosphorylation sites in the pre-CP extensions and to study their importance for virus infectivity.

\section{RESULTS}

Mapping phosphorylation sites within the CaMV pre-CP N-terminal extension.

A previous study had indicated that, in addition to the main phosphorylation sites in p44 (S82, S86, and S88), the N- and C-terminal extensions of CaMV pre-CP also contain CKII phosphorylation sites (Chapdelaine et al. 2002). Putative target sites for the CKII protein kinase in the CP sequence, containing the motif $(\mathrm{S} / \mathrm{T}) \mathrm{XX}(\mathrm{D} / \mathrm{E})$ specific to most CKII phosphorylation sites, were identified using the ScanProsite program tool 
and NetPhosK 2.0 server at the ExPAsY molecular biology server of the Swiss Institute of Bioinformatics. We focused our study on some of the serine and threonine residues that are potential targets of the CKII serine or threonine kinase.

The amino acid sequences of the N-terminal (first 76 amino acids) and C-terminal (last 49 amino acids) extensions of CaMV pre-CP contain several clusters of $\mathrm{S}$ or $\mathrm{T}$ residues that potentially can be phosphorylated by CKII (Fig. 2A). The Nterminal 76 amino acid stretch contains nine $S$ residues at positions 4, 23, 25, 37, 48, 51, 66, 68, and 72, and the C-terminal region has seven $S$ residues at positions 473, 477, 480, 481, 483,486 , and 488 as well as three $\mathrm{T}$ residues at positions 472 , 474, and 482. To identify which residues are phosphorylated, we generated CaMV CP mutants where the $\mathrm{S}$ and $\mathrm{T}$ residues were substituted with A or D.

In the $\mathrm{N}$-terminal extension, the $\mathrm{S}$ residues were divided into five distinct clusters (Fig. 2A, I to V). The serines in each cluster were substituted by alanines and the resulting mutations were introduced into the recombinant protein CP 1-265 S82,86,88A $\left(\mathrm{CP}^{*}\right)$, in which S82, S86, and S88 already are mutated to A. The mutated ORFs were cloned in the $\mathrm{pET} 3 \mathrm{~d}$ vector, generating a series of constructs (CP* S4A, CP* S23,25A, CP* S37A, CP* S48,51A, and CP* S66,68,72A) (Fig. 2B, upper panel). The proteins were expressed, purified, and used as substrates for phosphorylation with and $[\gamma-32 \mathrm{P}]$ ATP using purified viral capsids as a source of CKII activity. As already reported (Chapdelaine et al. 2002), purified CP44 is phosphorylated by the virus-associated kinase (Fig. 3A; lane 1), thus serving as an internal control. Most of the mutants were efficiently phosphorylated in vitro, with the exception of $\mathrm{CP}^{*} \mathrm{~S} 66,68,72 \mathrm{~A}$, which was less well phosphorylated (Fig. 3A; and C, lane 7). Phosphorylation of this mutant was not completely abolished, however, indicating the presence of other minor CKII phosphorylation sites on the CP.

Indeed, CP 1-265 was more phosphorylated than CP 1-265 S82,86,88A (CP*) (Fig. 3A, lanes 8 and 9), but the level of phosphorylation observed here is lower than that observed previously by Chapdelaine and associates (2002). The variations in the signal probably are due to differences in the viral preparations - the content of CKII associated with the virion being difficult to control. To measure the level of phosphorylation more precisely, signal intensities were analyzed with the ImageQuant program on the phosphoimager. The signal of CP 1265 was taken as the standard (100\% phosphorylation). All mutated forms of the protein were compared with $\mathrm{CP}^{*}$ for statistical analysis (Fig. 3C). The results (Fig. 3C) revealed that
$\mathrm{CP}^{*}$ is indeed phosphorylated to a lesser extent than CP 1-265, but to a greater extent than $\mathrm{CP}^{*} \mathrm{~S} 66,68,72 \mathrm{~A}$ (both differences are statistically significant: $P<0.01$ by Dunnett's multiple comparison test).

To determine whether the three $\mathrm{S}$ residues in cluster $\mathrm{V}$ contributed equally to phosphorylation of $\mathrm{CP}$, we mutated serines 66, 68, and 72 two by two, generating CP* S66,68A, CP* S66,72A, and CP* S68,72A (Fig. 2B, upper panel). Replacement of two of the three serines in any combination had little effect on the phosphorylation level. The phosphorylation signals of CP* S66,68A (Fig. 3A, lane 10) and CP* S66,72A (lane 11) were comparable with that of $\mathrm{CP}^{*}(P>0,05)$. However, $\mathrm{CP}^{*}$ S68, 72A (lane 12) was less phosphorylated than the other two double mutants and significantly less so than $\mathrm{CP}^{*}(P<0.01)$ (Fig. 3C).

To mimic the phosphorylation state of the $\mathrm{CP}$, we substituted all the $\mathrm{S}$ residues of cluster $\mathrm{V}$ for $\mathrm{D}$ and generated $\mathrm{CP}^{*}$ S66,68,72D (Fig. 2B). Interestingly, these $S \rightarrow D$ substitutions restored phosphorylation of the protein; the signal is approximately $80 \%$ of that of $\mathrm{CP}^{*}$ and significantly different from CP* S66,68,72A (Fig. 3A; lane 13) $(P<0.01$ by Dunnett's multiple comparison test).

The C-terminal 49 amino acids of pre-CP contain seven $\mathrm{S}$ residues at positions $473,477,480,481,483,486$, and 488, and three $\mathrm{T}$ residues at positions 472,474 , and 482 (Fig. 2A). Multiple substitutions of these residues for A were introduced in CP 99-489 together with an N-terminal 6xHis tag (Fig. 2B, bottom panel). All mutants were phosphorylated at a level similar to CP 99-489 (Fig. 4C) and did not show any significant differences. However, the phosphorylation signal for CP 7SA + 3TA (lane 6) was significantly diminished compared with that of CP 99-489 $(P<0.01)$, indicating the presence of more than one site responsible for phosphorylation of the C-terminal domain (Fig. 4C).

\section{Phosphorylation of $\mathrm{N}$ - and $\mathrm{C}$ - terminal mutants with human CKII in vitro.}

CaMV CP was shown to be phosphorylated in vitro by the virus-associated kinase and purified Arabidopsis thaliana CKII, both of which have the same activity (Chapdelaine et al. 2002). To confirm our results, and to test the possibility that CaMV CP can be phosphorylated by a CKII from another source, we replaced purified virus as the source of kinase in the assay with a commercially available human recombinant CKII (New England Biolabs, Beverly, MA, U.S.A.). CKII specifically phosphory-

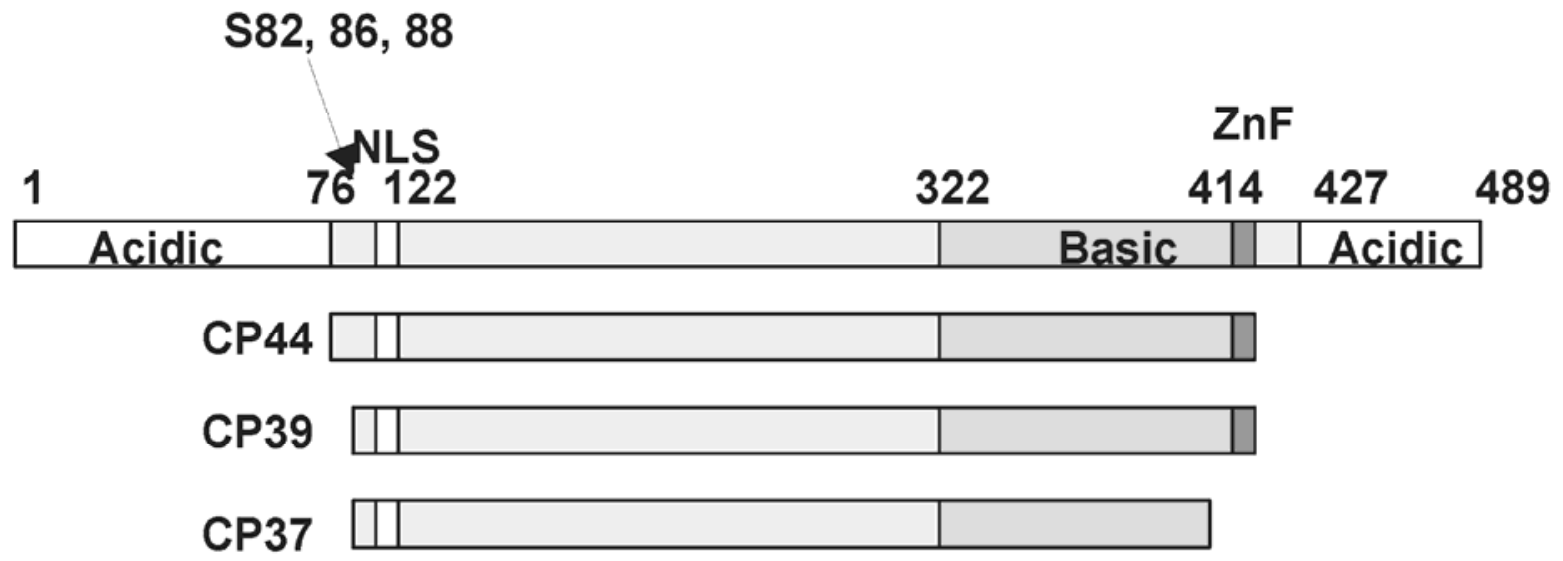

Fig. 1. Schematic representation of Cauliflower mosaic virus coat protein $(\mathrm{CP})$ precursor harboring $\mathrm{N}$ - and $\mathrm{C}$-termini which contained potential casein kinase II (CKII) phosphorylation targets. The previously identified target by CKII serines 82,86 , and 88 are shown, followed by the nuclear localization signal (NLS), the lysine-rich region (basic), and the Zinc-finger (ZnF). The three forms of the CP, CP44, CP39, and CP37, are shown underneath the precursor from which they are derived by further processing by the viral protease (cleavage site between amino acids 76 and 77 ). The N-terminus of $\mathrm{CP} 44$ (amino acid 77) and the proposed $\mathrm{N}$ and $\mathrm{C}$ termini of CP39 and CP37 are based on the study of Chapdelaine and associates (2002). 
lates $\mathrm{S}$ and $\mathrm{T}$ residues in the context $(\mathrm{S} / \mathrm{T}) \mathrm{XX}(\mathrm{DE})$ (Meggio and Pinna 2003) characterized by the presence of acidic residues at position $n+3$. Serines 66,68 , and 72 are good candidates because their environment is similar to that of $\mathrm{S} 82,86$, and 88, which were shown to be excellent phosphorylation targets. CP $\mathrm{N}$-terminal mutants were used as substrates in the presence of human CKII and $\left[\gamma-{ }^{32} \mathrm{P}\right]$ ATP. Autoradiography of the proteins revealed that all the $\mathrm{N}$-terminal mutant $\mathrm{CPs}$ became phosphorylated except for the triple mutant $\mathrm{CP}^{*}$ S66,68,72A, which was a poor substrate and led to an almost complete inhibition of phosphorylation compared with the control $\mathrm{CP}^{*}(P<0.01)$ (Fig. 3B, lane 6). As expected, $\mathrm{CP}^{*}$ was less phosphorylated than $\mathrm{CP} 1-$ $265(P<0.01)$. Indeed, CP* S66,68,72D was phosphorylated and the signal obtained was stronger than with $\mathrm{CP}^{*}(P<0.01)$ (Fig. 3D). When using human CKII alone, we observed autophosphorylation of its subunits, which serves as an internal control (Fig. 3B, lane 1). Usually, this signal is weak and hard to see on the gel.

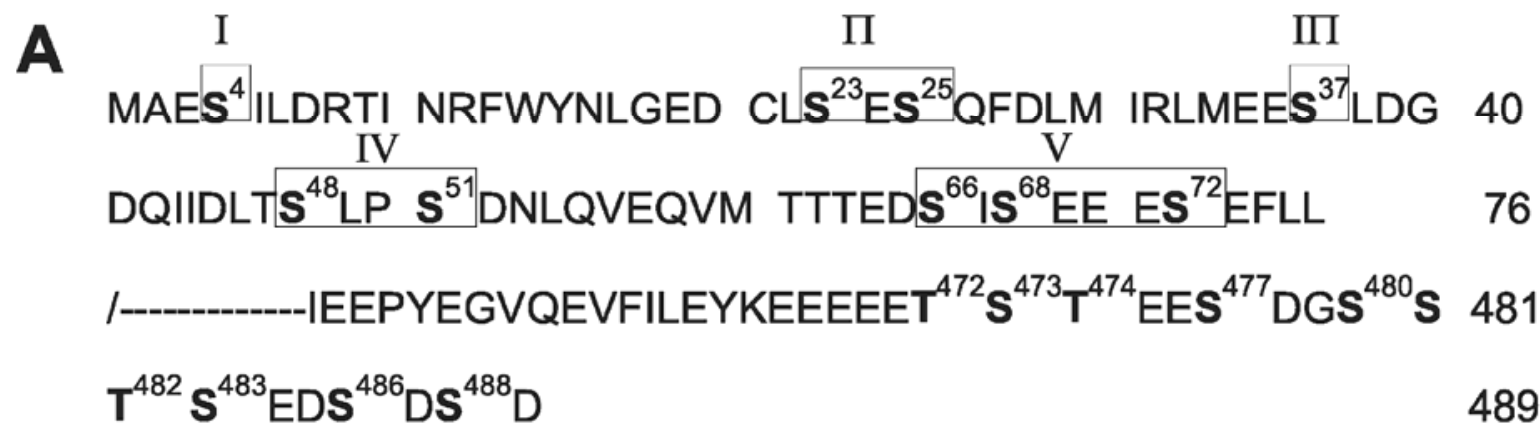

B

CP 1-265 S82,86,88A
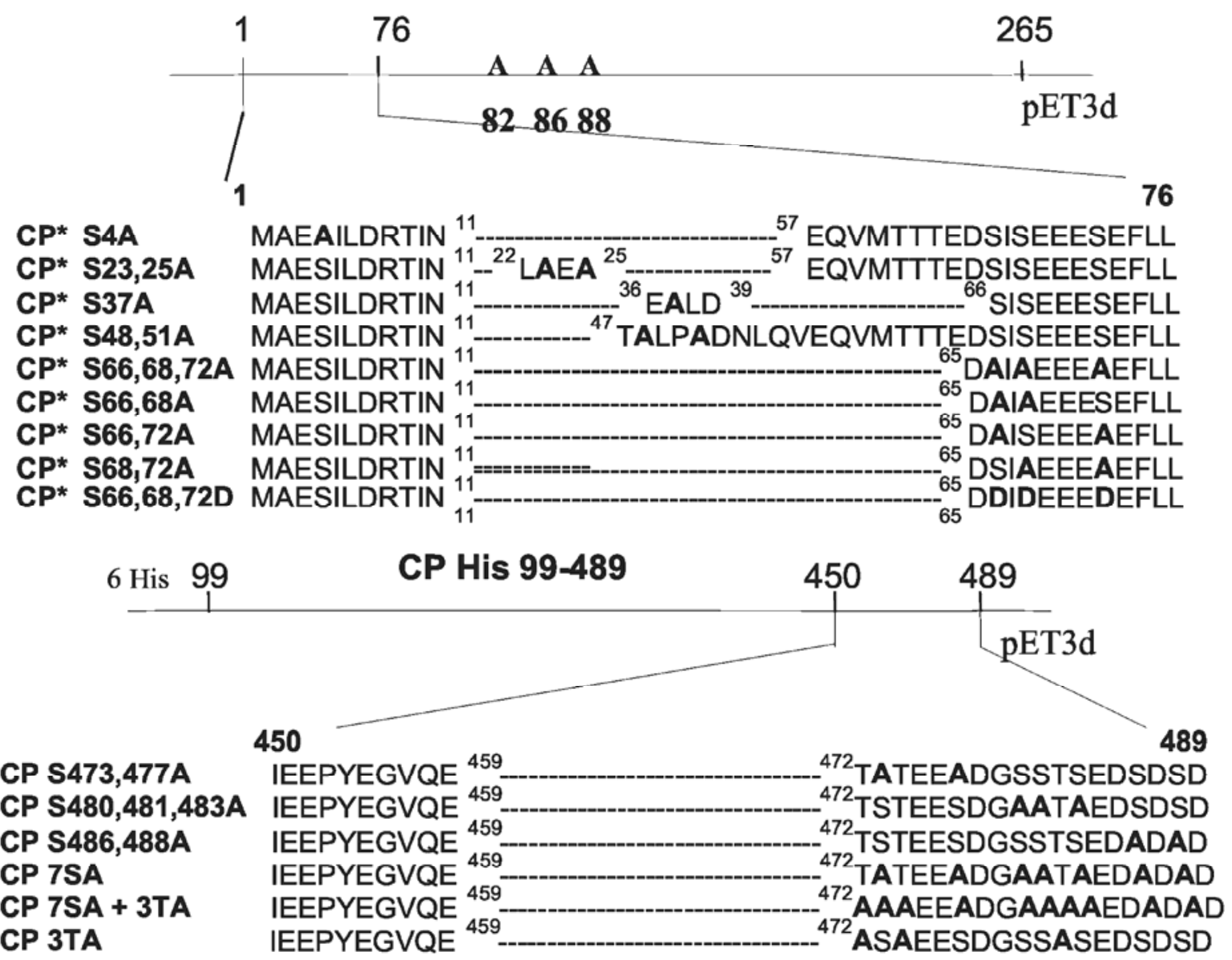

Fig. 2. A, Amino acid sequence of the N-terminal (first 76 amino acids) and C-terminal (last 49 amino acids) domains of the Cauliflower mosaic virus (CaMV) coat protein (CP) precursor. Putative phosphorylation targets are in bold and the five distinct clusters in the N-terminal extension (I to V) are boxed. B, CaMV CP substitution mutants in the context of CP* (amino acids 1 to 265 with serines 82, 86, and 88 already mutated to alanine) (N-terminal mutants) or 6xHis99-489 (C-terminal mutants). Constructs were cloned in pet3D vector, expressed in Escherichia coli, and used as substrates for the casein kinase II in vitro phosphorylation assay. CP mutants are named according to their amino acid substitutions. Serine (S) and threonine (T) residues mutated to alanine (A) are shown (mutated amino acids indicated in bold). 
The phosphorylation pattern observed with human CKII was comparable with that observed with the virus-associated kinase; however, the signals were stronger and more reproducible (Fig. 3D). A faint band for CP* S66,68,72A indicates that labeling of other residues, such as $\mathrm{T}$, might occur to a lesser extent. CP* S66,68,72D was phosphorylated, as also seen when the virus-associated kinase was used. Finally, and as expected, CP 1-265 was significantly more phosphorylated than CP* (Fig. 3D). The human casein kinase II gives a stronger and more reproducible signal, facilitating quantification of the signal in contrast to the virion associated CKII, which is more difficult to control.

A

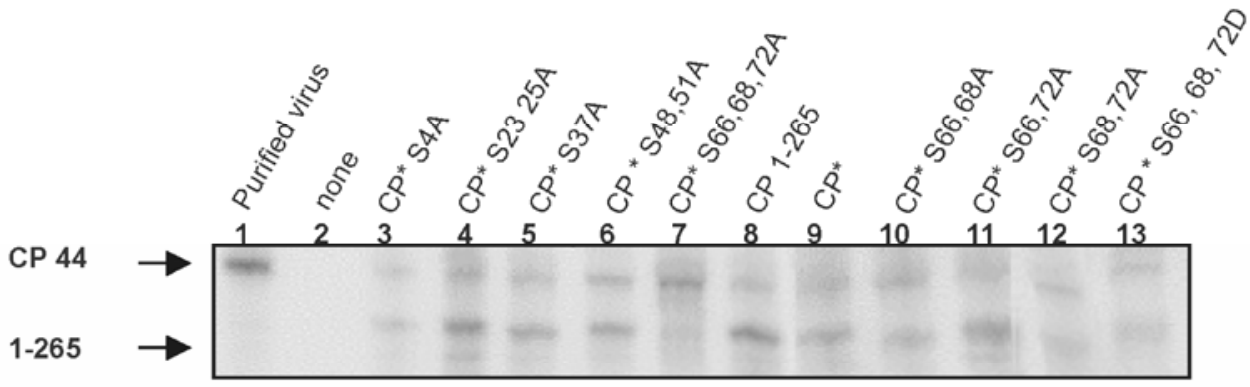

Western

Sypro orange

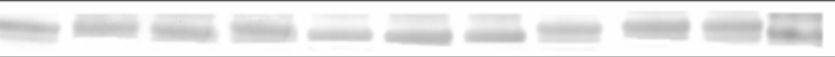

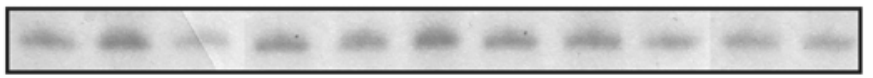

B

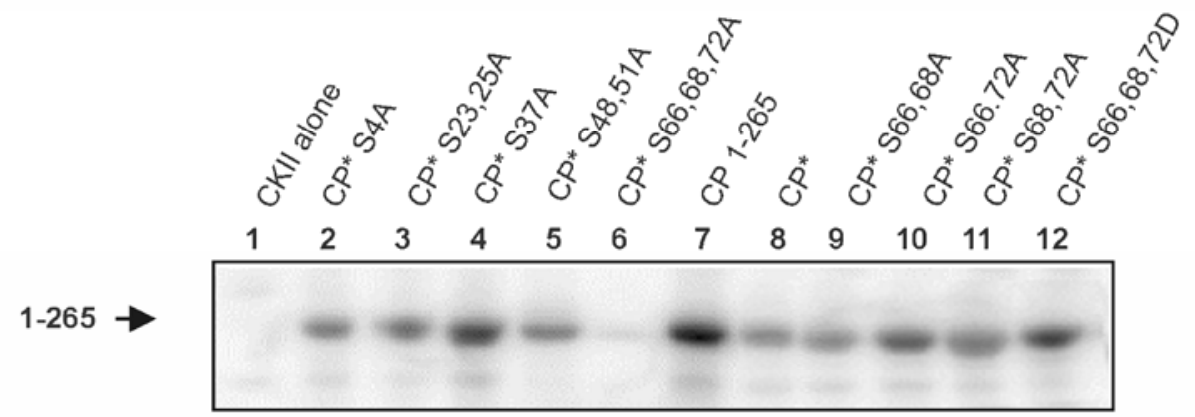

C

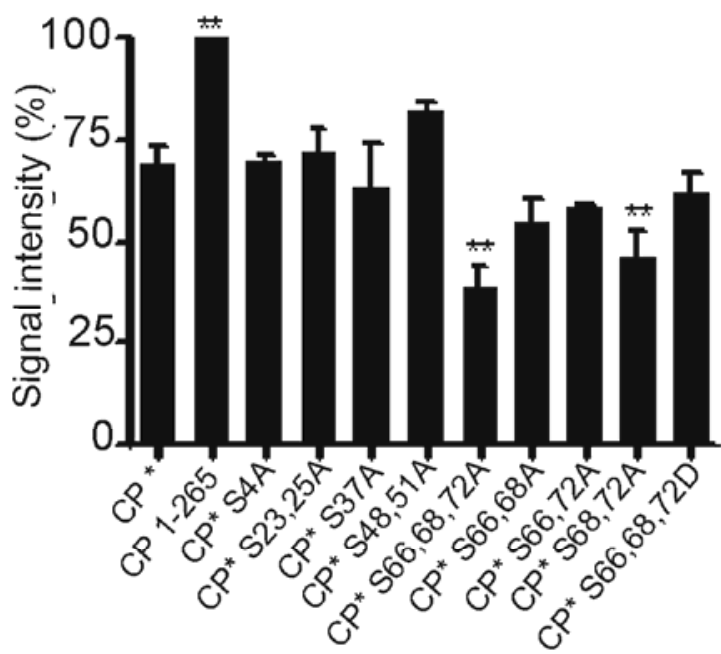

Recombinant human CKII phosphorylation

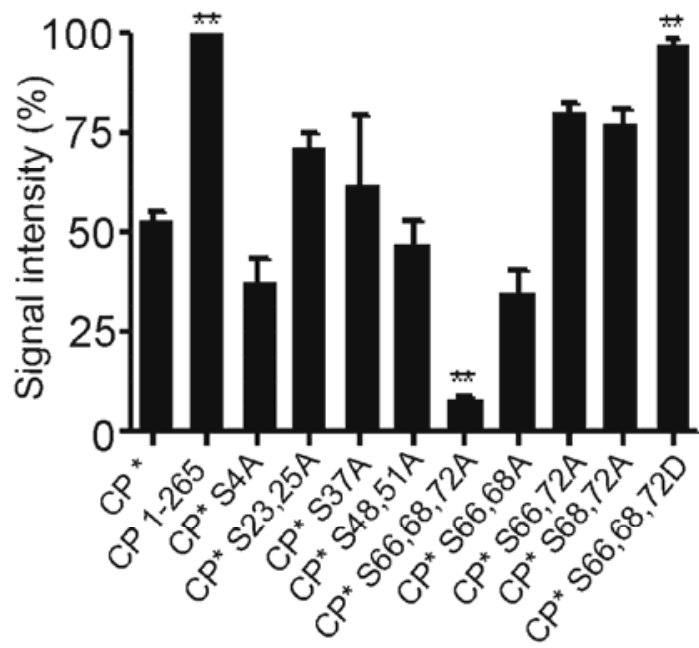

Fig. 3. Phosphorylation of recombinant coat protein (CP) N-terminal mutants with A, casein kinase II (CKII) activity of the host and B, human CKII. A, Equal amounts of wild-type (1-265), CP*, and N-terminal mutant proteins were phosphorylated with virus-associated kinase and $2.5 \mu \mathrm{Ci}$ of $\left[\gamma^{-}{ }^{32} \mathrm{P}\right] \mathrm{ATP}\left(3 \mathrm{~h}, 37^{\circ} \mathrm{C}\right)$. Purified virus and CP (1-265) alone served as controls. Phosphorylated proteins were detected with a phosphor screen on a Typhoon apparatus. The positions of the phosphorylated p44 and 1-265 polypeptides are indicated on the left. Proteins were quantified by staining sodium dodecyl sulfate (SDS) gels with sypro orange (1/5000). Duplicate gels were transferred onto nitrocellulose membrane for immunodetection (ECL system; Amersham) with anti pIV ${ }^{1-362}$ antibodies (Chapdelaine and Hohn 1998). B, Equal amounts of protein as in (A) quantified by staining SDS polyacrylamide gel electrophoresis gels with sypro orange and analyzed by Western blot were phosphorylated by human CKII $(250 \mathrm{U})$ and $\left[\gamma^{-}{ }^{32} \mathrm{P}\right] \mathrm{ATP}(2.5 \mu \mathrm{Ci})$ in a total volume of $30 \mu \mathrm{l}\left(30^{\circ} \mathrm{C}, 1 \mathrm{~h}\right)$. The arrow indicates the position of the corresponding 1-265 polypeptide. Phosphorylated proteins were detected with a phosphor screen and a Typhoon imager. $\mathbf{C}$ and $\mathbf{D}$, The intensity of signal in each band (percent phosphorylation) was analyzed and CP 1-265 was set as the standard (100\% of signal). Data shown represent means + standard error of the mean of four separated phosphorylation experiments for N-terminal CP constructs performed with C, virus-associated CKII and D, human CKII; ** indicates $P<0.01$, one-way analysis of variance, Dunnett's multiple test comparison test (compared with control CP*). 
Phosphorylation assays with human CKII revealed an important reduction in phosphorylation of mutant CP 7SA + 3TA, where all $\mathrm{S}$ and $\mathrm{T}$ residues between amino acids 472 and 489 of $\mathrm{CP}$ were mutated (Fig. 4B, lane 7). Mutation of all these sites significantly diminished the signal (Fig. 4D) $(P<0.01)$.
Mutants CP 3TA and CP 7SA also were phosphorylated at levels that are not significantly different from the reference $\mathrm{CP}$ 99-489. This result suggests that both $\mathrm{S}$ and $\mathrm{T}$ residues found between 472 and 489 are targets for both virus-associated and human CKII.

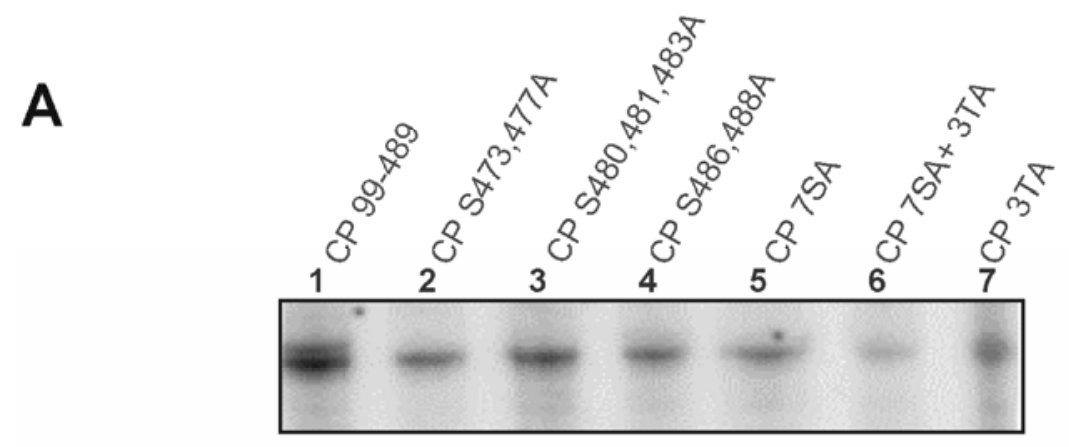

Western

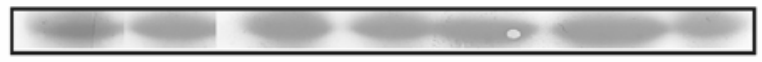

Sypro orange

B

$99-489$
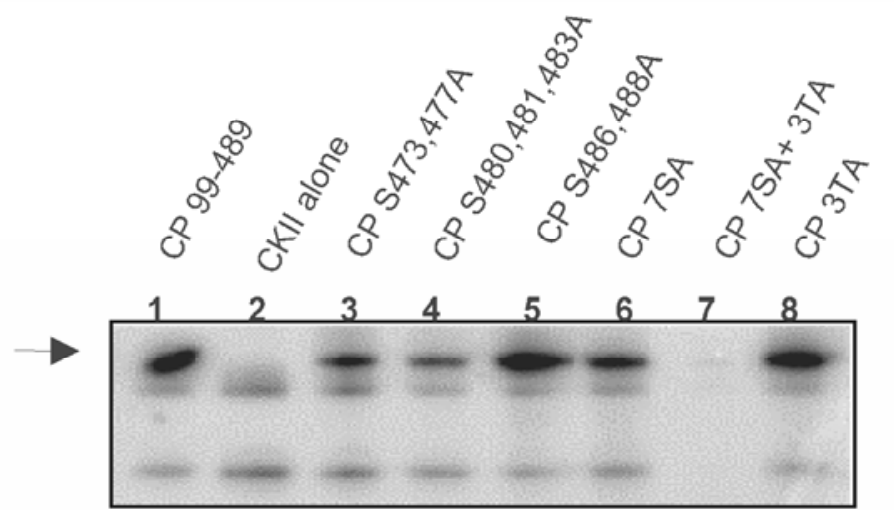

C

Virus associated CKII phosphorylation

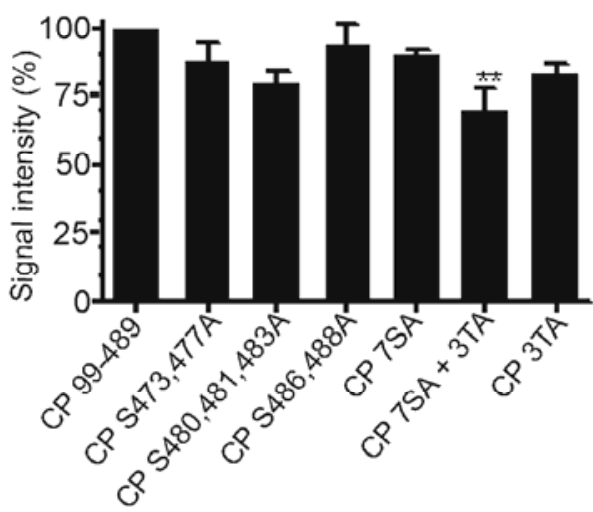

D Recombinant human CKII phosphorylation

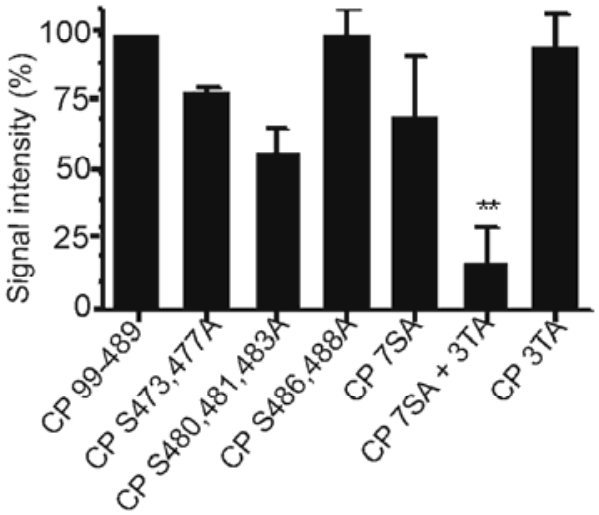

Fig. 4. Phosphorylation of Cauliflower mosaic virus coat protein (CP) C-terminal mutants with A, virus-associated casein kinase II (CKII) and B, human CKII. The arrow indicates the position of the corresponding 99-489 polypeptide. Equal amounts of mutant proteins in CP 6xhis99-489 (CP S473,477A; CP S480,481,482A; CP S486,488A; CP 7SA; CP 7SA + 3TA; CP 3TA; and CP 99-489 wild-type) were phosphorylated with A, virus-associated kinase and 2.5 $\mu \mathrm{Ci}$ of $\left[\gamma-{ }^{32} \mathrm{P}\right]$ ATP $\left(3 \mathrm{~h}, 37^{\circ} \mathrm{C}\right)$ or $\mathbf{B}$, human CKII $(250 \mathrm{U})$ and $\left[\gamma^{32} \mathrm{P}\right]$ ATP $(2.5 \mu \mathrm{Ci})$ in a total volume of $30 \mu \mathrm{l}\left(30^{\circ} \mathrm{C}, 1 \mathrm{~h}\right)$. Control assay with CKII alone also was performed. Phosphorylated proteins were detected with a phosphor screen on a Typhoon imager. Proteins were quantified by staining sodium dodecyl sulfate gels with sypro orange (1/5000). Duplicate gels were transferred onto nitrocellulose membrane for immunodetection (ECL system; Amersham) with anti $\mathrm{pIV}^{1-362}$ antibodies (Chapdelaine and Hohn 1998). C and D, The intensity of signal in each band (percent phosphorylation) were analyzed for each phosphorylation assay and CP 99-489 was set as the standard (100\% of signal). Data shown represent mean + standard error of the mean of four experiments performed independently; $* *$ indicates $P<0.01$, one-way analysis of variance, Dunnett's multiple test comparison test (compared with control CP 99-489). 
Infectivity of virus

with $\mathrm{N}$ - and $\mathrm{C}$-terminal phosphorylation site mutations.

To assess the effect of phosphorylation of the N- and C-terminal extensions on the virus life cycle, we substituted $\mathrm{S}$ residues within clusters $\mathrm{I}$ to $\mathrm{V}$ of the $\mathrm{N}$-terminus and both $\mathrm{S}$ and $\mathrm{T}$ residues at the C-terminus of the CP in the wild-type (WT) CaMV infectious isolate Cabb-B-S. Brassica rapa plants were inoculated with $1 \mu \mathrm{g}$ of WT or mutant CaMV viral DNAs (SalI digests of each clone). Particle bombardment was used for initiation of the infection instead of mechanical inoculation with Carborundum to improve reproducibility. CaMV mutant viruses S4A, S23,25A, S37A, and S48,51A were infectious, with normal mosaic symptoms appearing 14 to 21 days postinfection, which is comparable with the WT CaMV clone (Table 1). For one mutant, CaMV S66,68,72A, a delay of at least 2 weeks in the development of symptoms was observed, and only 2 of 16 inoculated plants showed symptoms after 35 days. Even after 2 months, the results remained similar for this mutant. Interestingly, the double mutants CaMV S66,68A, S66,72A, and $\mathrm{S} 68,72 \mathrm{~A}$ all were as infectious as the WT virus. As a negative control, plants were inoculated with mutant virus CaMV S82,86,88A, which was shown to be noninfectious as previously reported (Chapdelaine et al. 2002). CaMV S66,68,72D also was delayed in symptom appearance, showing that aspartic acid cannot replace S66, S68, and S72 to rescue viral replication.

Four passages with inoculum derived from infected leaves were performed. No difference in symptom appearance was observed. All the aforementioned mutant viruses showed symptoms and were similar to WT virus.

$$
0,1 \mu \mathrm{g}
$$
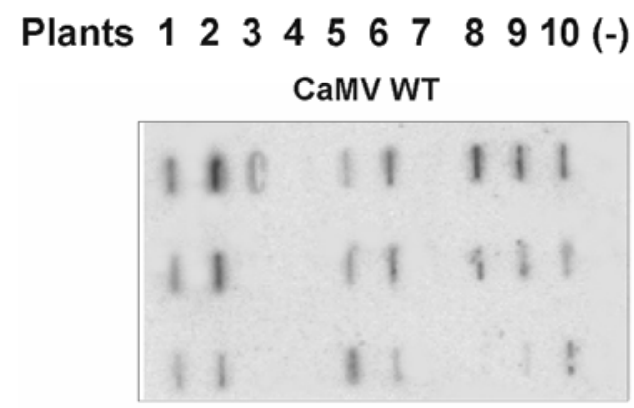

CaMV S66,68,72A

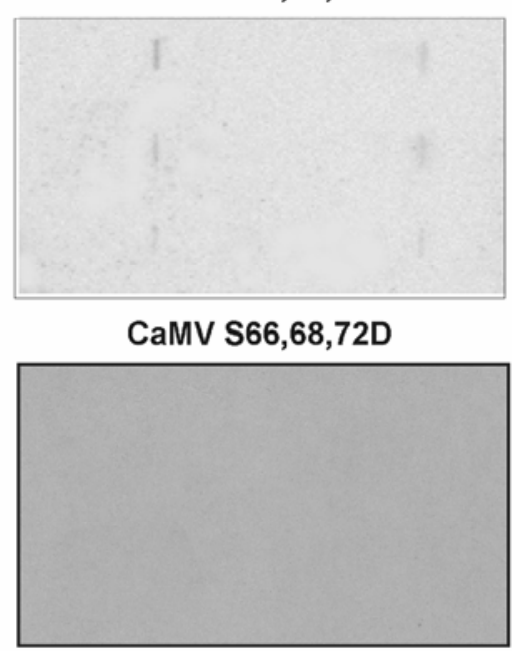

For CaMV mutants S66,68,72A and S66,68,72D, viral infectivity using a lower dose of DNA for inoculation also was tested. We inoculated 10 turnip plants with $0.1 \mu \mathrm{g}$ of DNA of mutant CaMV S66,68,72A, CaMV S66,68,72D, or WT CaMV DNA. Particle bombardment with $0.1 \mu \mathrm{g}$ of WT viral DNA into host plants led to development of strong systemic symptoms 14 days postinfection with no observable difference from plants inoculated with the higher dose $(1 \mu \mathrm{g})$. However, 28 days after inoculation with $0.1 \mu \mathrm{g}$ of CaMV S66,68,72A, there was a noticeable delay in infectivity and appearance of symptoms because only 2 plants out of 10 were infected. Moreover, the plants that showed infection were not as heavily infected as the control plants, as verified by dot-blot hybridization of leaf extracts of the inoculated plants using a radioactive probe (Fig. 5). CaMV S66,68,72D did not show any sign of symptoms and the leaves appeared to be free of viruses (Fig. 5).

We tested whether the C-terminal mutants affect virus infectivity in vivo. The C-terminal mutant CaMV 3TA was as infectious as CaMV WT, with no observable difference in symptoms between passages (Table 1). Viral DNA could be easily detected in these plants in the dot blot hybridization experiment (Fig. 5). The CaMV mutants 7SA and 7SA + 3TA, however, were not infectious in any of the plants inoculated by particle bombardment, even 2 months after inoculation. These plants were free of viral DNA as shown by the dot blot hybridization (Fig. 5).

\section{Stability of mutations.}

To monitor the appearance of reversions, viral DNAs of several inoculated plants (half of the plants showing symptoms)

\section{$1 \mu \mathrm{g}$}
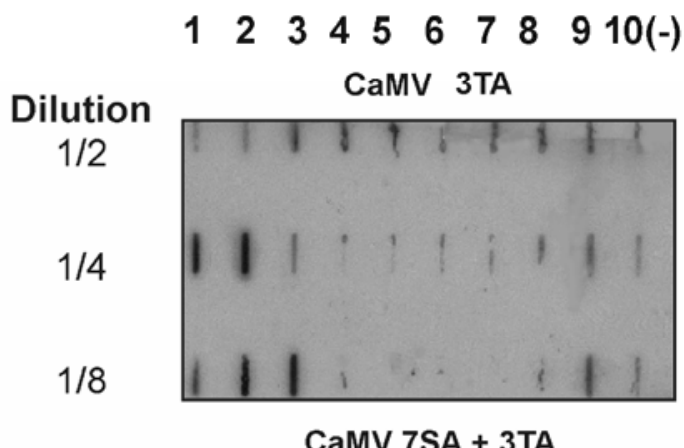

$1 / 2$

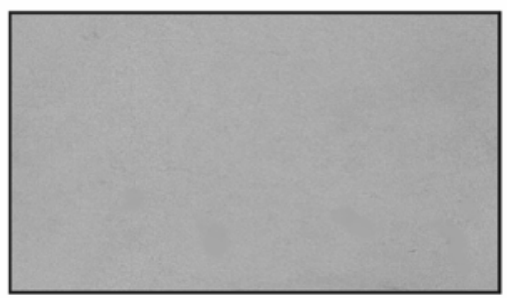

CaMV 7SA

$1 / 2$

$1 / 4$

$1 / 8$

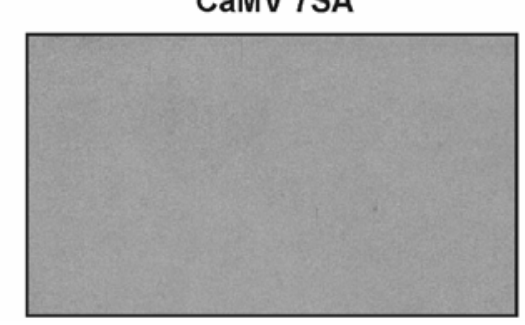

Fig. 5. Accumulation of Cauliflower mosaic virus (CaMV) mutant DNAs in turnip (Brassica rapa) was analyzed by dot blot hybridization. Tissue samples were taken 28 days postinoculation from the systemically infected leaves of plants inoculated with a 0.1- $\mu$ g-per-plant dose of wild-type (WT) CaMV or mutants S66,68,72A and S66,68,72D and a 1- $\mu$ g-per-plant dose of mutants 3TA, 7SA + 3TA, and 7SA. Serial dilutions (1:2 to 1:8) were made in Tris-EDTA buffer, and 50- $\mu \mathrm{l}$ samples of dilution were boiled and analyzed by dot blot hybridization with radioactive DNA probes covering the CaMV genome. A healthy plant was used as a negative control (-). 
were analyzed. After the second and fourth passages, systemically infected plants were harvested and total DNA extracts were used as templates to amplify the $\mathrm{CP}$ sequence by polymerase chain reaction (PCR). Amplified fragments were cloned and sequenced. Even after four passages, we observed no signs of reversion. In all cases, the introduced $\mathrm{CP}$ mutations were retained (data not shown).

\section{Effect on CP processing}

of $\mathrm{N}$ - and $\mathrm{C}$-terminal phosphorylation site mutations.

The consequence of mutating phosphorylation residues in the $\mathrm{N}$ - and $\mathrm{C}$-terminal sequences of pre-CP on $\mathrm{CP}$ processing was investigated by Western blot analysis (Fig. 6A and B). Protein extracts from plants inoculated with CaMV WT and mutant viruses were analyzed by Western blotting with anti-pIV ${ }^{1-362}$ antibodies. CaMV CP proteins from the purified virus were used as a control; the p44, p39, and p37 forms are visible in the viral purification (Fig. 6B, lane 1). All the mutants exhibited the p44 (44-kDa) and major CP p37 (37-kDa) bands seen in extracts from CaMV WT inoculated plants. Although we could not detect the p39 $(39-\mathrm{kDa})$ form, we propose that CPs harboring the mutations S66,68,72A, S66,68,72D, and 3TA were processed normally. As expected, no signal was detected in extracts of plants inoculated with CaMV 7SA and CaMV 7SA + 3TA, which are not infectious and serve as negative controls.

In the CaMV genome, the ORF of the CP (ORF IV) overlaps at its C-terminus by $39 \mathrm{nt}$ with ORF V, which encodes the viral protease. Thus, mutations of amino acids located between positions 478 and 489 of the CP potentially could affect the $\mathrm{N}$ terminus of ORF V and, consequently, viral infectivity. However, Torruella and associates (1989) previously showed that deletion of the N-terminal 16 amino acids (or first $48 \mathrm{nt}$ ) of ORF $V$ had no impact on the activity of the viral protease. Therefore, it is likely that our mutations affect virus infectivity only by interfering with the phosphorylation of the CP.

Table 1. Infection of Brassica rapa plants with Cauliflower mosaic virus (CaMV) clones harboring mutations of serine or threonine residues in $\mathrm{N}$ and C-terminal extensions of the capsid protein

\begin{tabular}{|c|c|c|}
\hline $\begin{array}{l}\text { Concentration, } \\
\text { CaMV mutant }\end{array}$ & Initial infection ${ }^{\mathbf{b}}$ & Symptom delay ${ }^{\mathrm{c}}$ \\
\hline \multicolumn{3}{|l|}{$1 \mu \mathrm{g}$} \\
\hline S4A & $4 / 4$ & No delay \\
\hline $\mathrm{S} 23,25 \mathrm{~S}$ & $4 / 4$ & No delay \\
\hline S37A & $4 / 4$ & No delay \\
\hline $\mathrm{S} 48,51 \mathrm{~A}$ & $4 / 4$ & No delay \\
\hline S66,68,72A & $2 / 16$ & 2 weeks \\
\hline S66,68A & $4 / 4$ & No delay \\
\hline S66,72A & $4 / 4$ & No delay \\
\hline $\mathrm{S} 68,72 \mathrm{~A}$ & $4 / 4$ & No delay \\
\hline S66,68,72D & $2 / 10$ & 2 to 3 weeks \\
\hline $\mathrm{S} 82,86,88 \mathrm{~A}$ & $0 / 4$ & $\ldots$ \\
\hline 3TA & $10 / 10$ & No delay \\
\hline $7 \mathrm{SA}$ & $0 / 10$ & $\ldots$ \\
\hline $7 \mathrm{SA}+3 \mathrm{TA}$ & $0 / 10$ & $\ldots$ \\
\hline WT & $14 / 14$ & No delay \\
\hline \multicolumn{3}{|l|}{$0.1 \mu \mathrm{g}$} \\
\hline WT & $8 / 10$ & No delay \\
\hline S66,68,72A & $2 / 10$ & 1 to 2 weeks \\
\hline S66,68,72D & $0 / 10$ & $\ldots$ \\
\hline \multicolumn{3}{|c|}{$\begin{array}{l}\text { a Concentration of infectious CaMV DNA clone for particle bombardment } \\
\text { delivery. WT = wild type. }\end{array}$} \\
\hline \multicolumn{3}{|c|}{$\begin{array}{l}\mathrm{b} \text { In all, } 4 \text { to } 16 \text { plants were tested depending of the delay in symptoms } \\
\text { appearance. Shown are number of plants infected/number of plants tested. } \\
\text { Mutant viruses were considered to be infectious if inoculated plants were } \\
\text { systematically infected showing typical mosaic symptoms. Monitoring of } \\
\text { symptoms was performed for } 2 \text { months. Initial infection with } 1 \text { and } 0.1 \mu \mathrm{g} \\
\text { of viral DNAs delivered by particle bombardment. }\end{array}$} \\
\hline \multicolumn{3}{|c|}{$\begin{array}{l}\text { c Symptom appearance was compared with the WT DNA clone-infected } \\
\text { plants showing systemic symptoms } 21 \text { days postinoculation. }\end{array}$} \\
\hline
\end{tabular}

\section{DISCUSSION}

The results presented here provide evidence that the $\mathrm{N}$ - and C- termini of the CaMV precapsid are phosphorylated by CKII protein kinase. We also showed that phosphorylation of the precapsid plays an important role in the infectivity of the virus. The substitution of S66, 68, and 72 for $\mathrm{A}$ at the N-terminus affected both phosphorylation in vitro and viral infectivity. These residues appear to be the major sites of phosphorylation in the $\mathrm{N}$-terminal extension. Interestingly, substitution of the three serines for negatively charged residues (D), which mimic the phosphorylated S, also was detrimental to viral infectivity. This mutant (D) was phosphorylated in vitro, suggesting that it is a substrate for CKII. Aspartic acid is not a natural substrate of CKII, and its phosphorylation by an unindentified kinase within the purified virus preparation or in the recombinant human CKII used in the in vitro assay is unlikely. A more plausible hypothesis is that the D substitutions create a favorable context for phosphorylation of $\mathrm{T}$ or $\mathrm{S}$ residues that are not naturally phosphorylated in the WT context. Consistent with this proposition, analysis of the $\mathrm{CP} \mathrm{N}$-terminal sequence harboring D substitutions for S66, 68, and 72 using the NetphosK 1.0 and NetPhos 2.0 server revealed that T62 becomes a new CKII phosphorylation target that is not predicted in the WT sequence (data not shown). Phosphorylation of T62 by CKII is a possible explanation for the signal observed in vitro with the S66,68,72D mutant. In addition, it is reasonable to predict that phosphorylation of residues S66, 68, and 72 in the WT context also could favor a secondary phosphorylation event on this residue in the life cycle of the virus.

We also showed that the C-terminal extension (472 to 489) is efficiently phosphorylated in vitro by CKII. Although several $\mathrm{S}$ and $\mathrm{T}$ residues in this area are putative targets for CKII, we were unable to identify specifically preferred targets for CKII in this extension. However, we clearly demonstrated that substitution of the $7 \mathrm{~S}$ or the $7 \mathrm{~S}+3 \mathrm{~T}$ clusters for A had a major impact on the infectivity of the virus, whereas mutation of

A

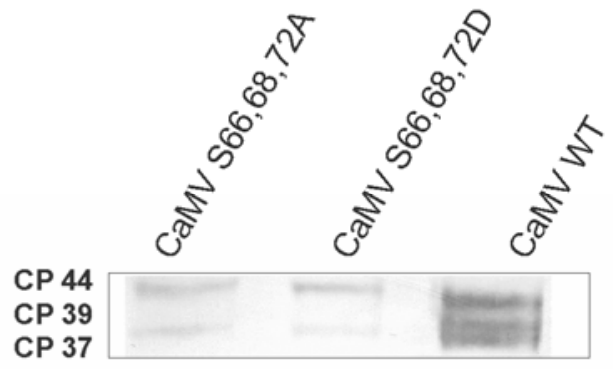

B

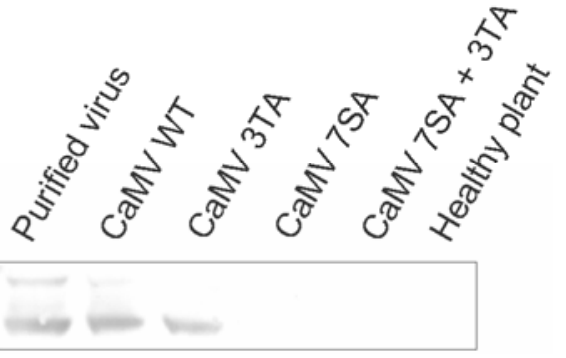

Fig. 6. Western analysis of Cauliflower mosaic virus (CaMV) coat proteins (CP) from purified virus and from plants inoculated with CaMV mutants. Total viral proteins were extracted from plants inoculated with viral DNAs harboring mutations in the $\mathrm{N}$ - and $\mathrm{C}$-terminal sequences of $\mathrm{CP}$ precursor (pre-CP). A, CaMV N-terminal mutant viruses. B, CaMV C-terminal mutant viruses. Proteins were transferred onto nitrocellulose and detected using antibody directed against the pre-CP anti-PIV ${ }^{1-362}$. The positions of CaMV proteins $\mathrm{CP} 44$, CP39, and CP37 are indicated on the left of the blots. 
only three phosphorylation targets (3TA) did not. Therefore, a high phosphorylation level in this area appears to be important for the virus life cycle.

Interestingly, phosphorylation and cleavage by the viral protease (PR) of the Gag polyproteins of retroviruses, which are related to the pararetrovirus family (Rothnie et al. 1994), is a prerequisite for virion maturation. A recent study has shown that phosphorylation of several of its cleavage intermediates likely precedes the cleavage of these domains by the viral protease in Simian immunodeficiency virus (SIV) (Rue et al. 2005). These results, coupled with studies of Gag proteins in other retroviruses, indicate that phosphorylation of Gag stimulates its cleavage by PR (Naso et al. 1979; Yoshinaka and Luftig 1982), which leads to the hypothesis that phosphorylation and proteolysis of Gag proteins may be functionally linked in SIV. The CaMV CP precursor also needs to be processed by the viral protease to complete its maturation. It is possible that phosphorylation of the termini plays a role in the activation of the viral protease and the maturation of the protein, which would explain the effect of the mutations introduced here on the infectivity of the virus. In some cases, maturation of mutant $\mathrm{S} 66,68,72 \mathrm{~A}$ could take place, as shown by the Western blotting of infected leaves (i.e., the virus was able to replicate inefficiently). However, in 14 of 16 plants inoculated with this mutant, replication was completely abortive.

The amino and carboxyl terminal domains of the precapsid have no significant homology with other known sequences in the database, and their exact function in the virus life cycle is still unknown. Although the amino acid sequences of the termini of caulimovirus capsid precursors are not conserved, they all contain putative instability elements at both ends (Karsies et al. 2001). Both extremities are cleaved during maturation of the $\mathrm{CP}$ and are absent in the purified virus. We previously proposed, based on gold-labeling electron microscopy of the $\mathrm{N}$ terminal extension, that it can play a role early in the assembly process by anchoring the precapsid prior to the assembly process (Champagne et al. 2004). In this model, the N- and C-terminal extensions are removed from the assembled particles by the viral protease, leading to accumulation of mature virus in the inclusion bodies. Consistent with this model, we previously showed that, when transiently expressed in plant protoplasts, the N-terminal extension retained the $\mathrm{CP}$ in the cytoplasm (Karsies et al. 2002). The presence of instability elements in the $\mathrm{N}$ - and C-terminal extensions of the precapsid (Karsies et al. 2001) are difficult to reconcile with the observation that the CaMV CP is the most abundant protein found in infected leaves. Phosphorylation events often are linked to protein degradation (Karsies et al. 2001, 2002; Leclerc et al. 1999). Therefore, we proposed that CaMV might mediate CKII phosphorylation of the precapsid in a regulated manner in order to maintain successful infection.

Based on previous reports and the results of this study, we propose that nonphosphorylated precapsid accumulates close to the plasma membrane of the infected cell. Upon accumulation of a sufficient amount of precapsid and viral RNA, the assembly process is triggered and particles made of the precapsid are formed. The CP termini then are phosphorylated to trigger their cleavage by the virally encoded protease, leading to maturation of the precapsid. In this model, the free phosphorylated extensions are targeted rapidly to the host degradation pathway (probably the proteasome) so as not to interfere with binding of the precapsid with an unknown receptor that is involved in the accumulation of the precapsid in close proximity to the cellular membrane. In this model, the S66,68,72A and the 7SA mutants would be deficient for replication because their respective termini compete for binding with the unknown receptor of the precapsid and interfere with the assembly process. The S66,68,72D mutant also is affected in its replication because the precapsid is rapidly targeted for degradation, which prevents its accumulation for efficient viral assembly.

\section{MATERIALS AND METHODS}

\section{Cloning procedures.}

PCR was performed using the Expand High Fidelity PCR system (Roche) and all PCR fragments were cloned and confirmed by DNA sequencing (ABI 3730/XL using the BigDye terminator reaction mix (Applied Biosystems, Foster City, CA, U.S.A.). Fragments of WT and mutated ORF IV were generated using CaMV Cabb-B-S (the CaMV genome cloned in the SalI site of pBR322; a kind gift from T. Hohn) as a template. CP clones 1265 and 1-265 S82,86,88A and CaMV CP S82,86,88A have been described previously (Chapdelaine et al. 2002). All restriction enzymes were purchased from New England Biolabs.

\section{Plant material and viral purification.}

B. rapa plants (var. "Just Right") were grown in a greenhouse at $20 \pm 2^{\circ} \mathrm{C}$ with a 16-h photoperiod. Two-week-old turnip plants were mechanically inoculated with CaMV-infected leaf sap for viral purification. The virus was purified as described previously (Hull and Shepherd 1976) with slight modifications. After the first high-speed ultracentrifugation, the pellet was homogenized and treated with $20 \%$ chloroform. The supernatant was overlaid onto a $15 \%$ sucrose cushion and centrifuged at $85,000 \times g$ in an SW60Ti rotor for $2 \mathrm{~h}$. The final pellet was resuspended in $0.1 \mathrm{M}$ Tris, $\mathrm{pH} 7.5$, and $2.5 \mathrm{mM} \mathrm{MgCl}_{2}$.

\section{Construction of CaMV virus clone mutants.}

$N$-terminal CP mutants. In mutants Ser 4; Ser 23,25; Ser 37; Ser 48,51; Ser 66,68,72; Ser 66,68; Ser 66,72; and Ser 68,72, $\mathrm{S}$ residues were substituted by alanine (A) coding triplets (GCG) and Ser 66,68,72 was replaced by the aspartic acid (D) coding triplet GAT. We also used CaMV Ser 82,86,88A mutant viral DNA as a noninfectious control. Mutations were generated by PCR using the WT cloned DNA (Cabb-B-S in pBR322) as template. For each single, double, and triple mutation, complementary and mutagenic primers were designed (Table 2, sections A through C; mutant codons are in bold). A two-step PCR was performed, with two separate PCR fragments being generated in the first step. The first was generated using the sense primer oligo $\mathrm{XhoI}$ with the respective antisense primers: oligo S4A(-) for CaMV S4A; oligo S23-25A(-) for CaMV S23,25A; oligo S37A(-) for CaMV S37A; oligo S4851A(-) for CaMV S48,51A; oligo S66-68-72A(-) for CaMV S66,68,72A; oligo S66-68A(-) for CaMV S66,68A; oligo S6672A(-) for CaMV S66,72A; oligo S68-72A(-) for CaMV S68,72A; and oligo S66,68,72D(-) for CaMV S66,68,72D. A second set of PCR fragments was generated with antisense primer 9484 as described (Chapdelaine et al. 2002) and the respective complementary primer $(+)$ (Table 2 , section $C$ ) corresponding to the antisense primer used for amplification of the first PCR fragment for each of the nine CP mutants. Pairs of PCR amplification products corresponding to each mutant were used in a second round of PCR amplification with primers $X h o I$ and 9484 . The resulting fragments then were digested with XhoI (unique site in ORF II) and $H p a I$ (unique site in ORF IV) and cloned in place of the corresponding WT fragment (XhoI-HpaI) in the cloned viral DNA. To generate viral DNA for infection, full-length viral sequences were excised from the vector and ligated prior to inoculation.

C-terminal CP mutants. Ser 473, 477, 480, 481, 483, 486, and 488 (7S); Thr 472, 474, and 482 (3T); and also all seven serines and three threonines together $(7 \mathrm{~S}+3 \mathrm{~T})$ were substituted by alanine (A) codon triplets (Table 2, in bold) using 
CaMV cloned in pBr322 vector as template. Two fragments were amplified for each mutant as above: CaMV 3TA, with primers HpaI with oligo 3TA(-) and oligo 3TA(+) with EagI; CaMV 7SA, with primers $H p a I$ with oligo 7SA(-) and oligo $7 \mathrm{SA}(+)$ with EagI; and CaMV 7SA + 3TA, with primers HpaI with oligo 7SA +3TA(-) and oligo 7SA +3TA(+) with EagI. The two PCR fragments specific for each mutant then were annealed with primers HpaI and EagI. The fragments then were digested with HpaI (unique site in ORF IV) and EagI (unique site in pBR322) and cloned in place of the WT fragment (HpaI-EagI) in the cloned viral DNA followed by excision and ligation.

\section{Infection by bombardment}

of plants and mechanical inoculation.

Isolate Cabb-B-S was used for infection tests of mutant viruses. In all, 4 to 16 turnip plants ( 2 weeks old) each were infected with WT and mutant infectious CaMV clones after SalI digestion and recircularization. A Helios Gene Gun system (Bio-Rad, Hercules, CA, U.S.A.) was used to prepare CaMV DNA-coated microcarrier cartridges. WT and mutant viral DNAs $(1 \mu \mathrm{g})$ previously precipitated with a $1.6-\mu \mathrm{m}$ gold microcarrier were injected into plant cells by particle bombardment in accordance with the manufacturer's instructions. CaMV S66,68,72A and WT viral DNAs $(0.1 \mu \mathrm{g})$ also were used for particle bombardment delivery. Appearance of symptoms was monitored. Twenty-one days postinoculation, or when symptoms were systemic, we used sap from infected plants plus Carborundum to mechanically inoculate a new series of plants; this manipulation was repeated for four passages. After each passage, we extracted total DNA and amplified the CP region by PCR to check for the appearance of revertants. Amplified fragments were sequenced directly or recloned in $\mathrm{pET} 3 \mathrm{~d}$ vector (New England Biolabs).

Table 2. Oligonucleotides used as primers for open reading frame IV mutagenesis

\begin{tabular}{|c|c|}
\hline Primers, name ${ }^{a}$ & Sequence $^{\mathrm{b}}$ \\
\hline \multicolumn{2}{|l|}{ A. Sense } \\
\hline XhoI & 5'-GATTACTCGAGCCAACTAAAGGAAATA-3' \\
\hline HpaI & 5'-AGCTGTTAACACGCTTTAGGCATGAAGCT-3' \\
\hline 9483 NEW & 5'-GCTCCAGCACCATGGCCGAA-3' \\
\hline 9483 & 5'-GCTCCAGCACCATGGCCGAATC-3' \\
\hline N-ter 99 His & 5'-AGCTACCATGGCCCACCATCACCATCACCATGATCGAACAGGAGGAACGGAGATTCCAAAA-3' \\
\hline \multicolumn{2}{|l|}{ B. Antisense } \\
\hline 9484 & 5'-CATCGGATCCTCAGTCTGAGTCT-3' \\
\hline EagI & 5'-AGCTCGGCCGCCATGCCGGCGATAATGGCCTGCTTCT-3' \\
\hline Oligo mut S4A & 5'-CCTATTAATGGTTCTGTCTAAAATCGCTTCGGCCA-3' \\
\hline 9485 New & 5'-CGGGATCCTCATGTAAATTCCTCAAGGTA-3' \\
\hline C-term CP S473-477A & $\begin{array}{l}\text { 5'-AGCTGGATCCTCAGTCTGAGTCTGAGTCTTCAGAAGTAGATGATCCATCCGCTTCTTCTGTCGCGG } \\
\text { TTTCTTC-3' }\end{array}$ \\
\hline C-term CP S480-481-483A & 5'-AGCTGGATCCTCAGTCTGAGTCTGAGTCTTCCGCAGTCGCCGCTCCATCACT-3' \\
\hline C-term CP S486-488A & 5'-AGCTGGATCCTCAGTCCGCGTCCGCGTCTTCAGAAGT-3' \\
\hline C-term 7SA & $\begin{array}{l}\text { 5'-AGCTEGATCCTCAGTCCGCGTCCGCGTCTTCCGCAGTCGCCGCTCCATCCGCTTCTTCTGTCGCGGT } \\
\text { TTCTTC-3' }\end{array}$ \\
\hline $\mathrm{C}$-term 7SA + 3TA & $\begin{array}{l}\text { 5'-AGCTGGATCCTCAGTCCGCGTCCGCGTCTTCCGCCGCCGCCGCTCCATCCGCTTCTTCCGCCGC } \\
\text { CGCTTCTTCTTCCTC-3' }\end{array}$ \\
\hline C-term 3TA & $\begin{array}{l}\text { 5'-AGCTGGATCCTCAGTCTGAGTCTGAGTCTTCAGACGCAGATGATCCATCACTTTCTTCCGCAGA } \\
\text { CGCTTCTTCTTCCTC-3' }\end{array}$ \\
\hline \multicolumn{2}{|l|}{ C. Complementary } \\
\hline oligo S4A (-) & 5'-AATGGTTCTGTCTAAAATCGCTTCGGCCATCCTGCT-3' \\
\hline$(+)$ & 5'-AGCAGGATGGCCGAAGCGATTTTAGACAGAACCATT-3' \\
\hline oligo S23-25A (-) & 5'-TTATCATAAGATCGAATTGCGCTTCCGCGAGACAATCTTCTCCC-3' \\
\hline$(+)$ & 5'-GGGAGAAGATTGTCTCGCGGAAGCGCAATTCGATCTTATGATAA-3' \\
\hline oligo S37A (-) & 5'-TAGATCAATAATTTGGTCCCCGTCAAGCGCCTCTTCCATCAATCTTAT-3' \\
\hline$(+)$ & 5'-ATAAGATTGATGGAAGAGGCGCTTGACGGGGACCAAATTATTGATCTA-3' \\
\hline oligo S48-51A (-) & 5'-TTCAACCTGCAAATTATCCGCAGGTAGCGCGGTTAGATCAATAATTTG-3' \\
\hline$(+)$ & 5'-CAAATTATTGATCTAACCGCGCTACCTGCGGATAATTTGCAGGTTGAA-3' \\
\hline oligoS66-68-72A (-) & 5'-TGCTAGAAGGAATTCCGCTTCTTCTTCCGCGATCGCGTCTTCGGTAGT-3' \\
\hline$(+)$ & 5'-ACTACCGAAGACGCGATCGCGGAAGAAGAAGCGGAATTCCTTCTAGCA-3' \\
\hline oligo S66-68A (-) & 5'-TGCTAGAAGGAATTCTGATTCTTCTTCCGCGATCGCGTCTTCGGTAGT-3' \\
\hline$(+)$ & 5'-ACTACCGAAGACGCGATCGCGGAAGAAGAATCAGAATTCCTTCTAGCA-3' \\
\hline oligo S66-72A (-) & 5'-TGCTAGAAGGAATTCCGCTTCTTCTTCCGAGATCGCGTCTTCGGTAGT-3' \\
\hline$(+)$ & 5'-ACTACCGAAGACGCGATCTCGGAAGAAGAAGCGGAATTCCTTCTAGCA-3' \\
\hline oligo S68,72A (-) & 5'-TGCTAGAAGGAATTCCGCTTCTTCTTCCGCGATTGAGTCTTCGGTAGT-3' \\
\hline$(+)$ & 5'-ACTACCGAAGACTCAATCGCGGAAGAAGAAGCGGAATTCCTTCTAGCA-3' \\
\hline oligoS66-68-72D (-) & 5'TGCTAGAAGGAATTCATCTTCTTCTTCATCGATATCGTCTTCGGTAGT-3' \\
\hline$(+)$ & 5'-ACTACCGAAGACGATATCGATGAAGAAGAAGATGAATTCCTTCTAGCA-3' \\
\hline oligo 3TA (-) & 5'-TGAGTCTTCAGACGCAGATGATCCATCACTTTCTTCCGCAGACGCTTCTTCTTC-3' \\
\hline$(+)$ & 5'-GAAGAAGAAGCGTCTGCGGAAGAAAGTGATGGATCATCTGCGTCTGAAGACTCA-3' \\
\hline oligo 7SA (-) & 5'-TGCTCAGTCCGCGTCCGCGTCTTCCGCAGTCGCCGCTCCATCCGCTTCTTCTGTCGCGGTTTCTTC-3' \\
\hline$(+)$ & $\begin{array}{l}\text { 5'-GAAGAAACCGCGACAGAAGAAGCGGATGGAGCGGCGACTGCGGAAGACGCGGACGCGGAC } \\
\text { TGAGCA-3' }\end{array}$ \\
\hline oligo 7SA + 3TA $(-)$ & $\begin{array}{l}\text { 5'-ACCTGCTCAGTCCGCGTCCGCGTCTTCCGCCGCCGCCGCTCCATCCGCTTCTTCCGCCGCCGCTTC } \\
\text { TTCTTCCTC-3' }\end{array}$ \\
\hline$(+)$ & $\begin{array}{l}\text { 5'-GAGGAAGAAGAAGCGGCGGCGGAAGAAGCGGATGGAGCGGCGGCGGCGGAAGACGCGGAC } \\
\text { GCGGACTGAGCAGGA-3' }\end{array}$ \\
\hline
\end{tabular}

${ }^{\text {a }}$ Complementary $=$ antisense and sense complementary oligonucleotides pairs.

${ }^{\mathrm{b}}$ Restriction sites in the primer sequence are underlined: BamHI GGATCC, EagI CGGCCG, HpaI GTTAAC, NcoI CCATGG, and XhoI CTCGAG. The mutated codon are indicated by bold letters; sense primer $(+)$ and antisense $(-)$ primer. 


\section{Protein extraction.}

To study the effect of phosphorylation on capsid processing during viral maturation, we collected systemically infected leaves for total protein extraction. Infected leaves $(120 \mathrm{mg})$ were homogenized with a pestle in liquid nitrogen. After addition of two volumes of Tris-EDTA buffer $(10 \mathrm{mM}$ Tris- $\mathrm{HCl}$, $\mathrm{pH} \mathrm{7.4,} \mathrm{and} 1 \mathrm{mM}$ EDTA), proteins were extracted with phenol and precipitated with methanol. Protein samples $(10 \mu \mathrm{l})$ were analyzed by electrophoresis on $10 \%$ tricine sodium dodecyl sulfate polyacrylamide gel electrophoresis (SDS-PAGE) gels (Schagger and von Jagow 1987) and transferred to nitrocellulose membranes for Western blot analysis. Membranes were blocked in Tris-buffered saline (TBS) with 5\% dry milk for $1 \mathrm{~h}$ at room temperature, before being probed with rabbit anti pIV $^{1-362}$ antibodies (1:2000) (raised against amino acids 1 to 362 of the CP) (Chapdelaine and Hohn 1998). Binding of primary antibody was detected with HRP-conjugated antibodies (Amersham Pharmacia Biotech, Uppsala, Sweden) and chemiluminescent immunodetection reagent as described by the manufacturer (ECL system; Amersham).

\section{Expression and purification}

\section{of recombinant CaMV CP (1 to 265).}

Fragments corresponding to amino acids 1 to 265 , and 1 to 265 with the three $\mathrm{Ser} \rightarrow$ Ala mutations at positions 82, 86, and 88 of the CaMV CP cloned in the expression vector pET3d, already were available in our laboratory (Chapdelaine et al. 2002). The recombinant proteins were overexpressed in Escherichia coli BL21(DE3) by $1 \mathrm{mM}$ isopropyl-D-thiogalactopyranoside induction at $37^{\circ} \mathrm{C}$ for $3 \mathrm{~h}$. Cells were harvested and resuspended in buffer (50 mM Tris, $\mathrm{pH} 8,300 \mathrm{mM} \mathrm{NaCl}, 0.1 \%$ Tween 20, $2 \mathrm{mM}$ 2-mercaptoethanol, $20 \mu \mathrm{M}$ phenylmethylsulfonyl fluoride (PMSF), and lysozyme at $0.02 \mathrm{mg} / \mathrm{ml}$ ). Cells were disrupted by sonication and purified as previously described (Chapdelaine and Hohn 1998). Briefly, pIV 1-265 and pIV 1-265 S82,86,88A proteins were isolated from bacterial inclusion bodies solubilized in $8 \mathrm{M}$ urea and renatured by dialysis against $0.5 \times$ TBS.

\section{Mutagenesis and preparation of CaMV CP mutant proteins.}

To construct CaMV CP N-terminal mutants, all mutations were introduced into plasmid pET3d containing CP $1-265$ $\mathrm{S} 82,86,88 \mathrm{~A}$, in which the serine residues identified as phosphorylation sites by Chapdelaine and associates (2002) already are mutated to alanine. We substituted serine with alanine in five different clusters (I to V) in the 1-to-76 sequence by PCRmediated mutagenesis, generating mutants $\mathrm{CP}$ S4A; CP S23,25A; CP S37A; CP S48,51A; and CP S66,68,78A. We also generated point mutations in the fifth cluster: $\mathrm{CP}$ S66,68A; CP S66,72A and CP S68,72A; and CP S66,68,72D Mutant constructs were generated in a two-step PCR performed using pET3d 1-265 S82,86,88A as the template. In the first round of PCR, two fragments were amplified for each mutant (Table 2; oligonucleotides are listed). The first fragment was amplified with sense oligo 9483 NEW and oligo mut S4A for CP S4A, and other mutants with sense oligo 9483 and the corresponding antisense oligo corresponding to each $\mathrm{CP}$ mutant: oligo S23-25A(-) for CP S23,25A; oligo S37A(-) for CP S37A; oligo S48-51A(-) for CP S48,51A; oligo S66-68-72A(-) for CP S66,68,72A; oligo S66-68A(-) for CP S66,68A; oligo $\mathrm{S} 66-72 \mathrm{~A}(-)$ for $\mathrm{CP} \mathrm{S} 66,72 \mathrm{~A}$; oligo $\mathrm{S} 68-72 \mathrm{~A}(-)$ for $\mathrm{CP}$ S68,72A; and oligo S66-68-72D(-) for CP S66,68,72D. Second fragments were amplified with primers complementary (Table 2 , section $\mathrm{C}$; sense primers $(+)$ ) to the respective mutagenic oligonucleotide used for amplification of the first fragment, and antisense oligo $9485 \mathrm{New}$. For the second round of PCR,
PCR fragments 1 and 2 were used as template with primers 9483NEW and 9485NEW for CP S4A and 9483 and 9485NEW for the other CP mutants. After BamHI and NcoI digestion, the resulting PCR products were ligated into the pET3d vector. All clones were verified by sequence analysis. Mutant proteins were purified by the same protocol used for WT protein CP 1-265 and CP 1-265 S88,86,88A. Proteins were analyzed by $10 \%$ SDS-PAGE and Western blot with pIV $^{1-362}$ antibodies (data not shown).

To construct C-terminal CP His-tag mutants, we amplified amino acids 99 to 489 of CaMV pre-CP protein using CaMV Cabb-B-S as template. Mutations were introduced by using mutagenic oligonucleotides with a sense primer containing six consecutive histidines (6xHis tag) located at the $\mathrm{N}$ terminus of all constructs. Mutant constructs were cloned in the pET3d expression vector. Six different mutants were generated: $\mathrm{CP}$ S473,477A; CP S480,481,483A; CP S486,488A; CP T $472,474,482 \mathrm{~A}$ (3TA); and substitution of all serines and threonines together (7SA + 3TA) with alanines. The sense primer $\mathrm{N}$-ter 99 His was used with the respective antisense primer containing a BamHI site 3'-GGATCC-5': C-term CP S473-477A for CP 99489 S473,477A; C-term CP S480-481-483A for CP 99-489 S480,481,483A; C-term CP S486-488A for CP 99-489 S486,488A; C-term 7SA for CP 99-489 7SA; C-term 7S-A + 3T-A for CP 99-489 7SA + 3TA; and C-term 3TA for CP 99-489 3TA. After digestion with $N c o$ I and BamHI, the amplified sequences were inserted into the BamHI and NcoI cloning sites of the $\mathrm{pET} 3 \mathrm{~d}$ vector.

His-tagged $\mathrm{CP}$ proteins were purified under native conditions according to the method supplied by Qiagen (Hilden, Germany). Recombinant WT and mutant proteins were solubilized from bacterial pellets in ice-cold lysis buffer $\left(50 \mathrm{mM} \mathrm{NaH}_{2} \mathrm{PO}_{4}, \mathrm{pH}\right.$ $8 \cdot 0,300 \mathrm{mM} \mathrm{NaCl}, 10 \mathrm{mM}$ imidazol, $20 \mathrm{mM}$ PMSF) by sonication. Samples were incubated in $1 \mathrm{ml}$ of Ni-NTA beads (Qiagen) with slight agitation for $2 \mathrm{~h}$ at $4^{\circ} \mathrm{C}$. Lysates were loaded onto a column and the beads were washed with $50 \mathrm{ml}$ of lysis buffer followed by $50 \mathrm{ml}$ of $50 \mathrm{mM} \mathrm{NaH}_{2} \mathrm{PO}_{4}, \mathrm{pH} 8 \cdot 0$, $500 \mathrm{mM} \mathrm{NaCl}, 20 \mathrm{mM}$ imidazol, $50 \mathrm{ml}$ of $50 \mathrm{mM} \mathrm{NaH} \mathrm{PO}_{4}$, $\mathrm{pH} 8 \cdot 0,700 \mathrm{mM} \mathrm{NaCl}$, and $50 \mathrm{mM}$ imidazol. The beads then were washed with $50 \mathrm{ml}$ of $10 \mathrm{mM}$ Tris- $\mathrm{HCl}, \mathrm{pH} \mathrm{8.0,} \mathrm{and} 50$ $\mathrm{mM}$ imidazol. CaMV proteins were eluted in elution buffer containing Tris- $\mathrm{HCl} 10 \mathrm{mM}, \mathrm{pH} 8.0$, and $250 \mathrm{mM}$ imidazol. Homogeneity of the purified proteins was determined by $10 \%$ SDS-PAGE and confirmed by Western immunoblot analysis using po58 rabbit polyclonal antibodies against amino acids 1 to 362 of the CP (Chapdelaine and Hohn 1998).

\section{In vitro phosphorylation.}

In vitro phosphorylation assays were carried out using equal amounts of recombinant $\mathrm{CP}$ mutant proteins in phosphorylation buffer (20 mM Tris- $\mathrm{Cl}, 10 \mathrm{mM} \mathrm{MnCl}_{2}, 0.8 \mathrm{mM}$ dithiothreitol, and $0.25 \mathrm{mM}$ EDTA) in the presence of $2.5 \mu \mathrm{Ci}$ of $[\gamma-$ $\left.{ }^{32} \mathrm{P}\right]$ ATP $(3,000 \mathrm{Ci} / \mathrm{mmol}$; Perkin-Elmer, Wellesley, MA, U.S.A.) and approximately $15 \mu \mathrm{g}$ of CaMV particles as a source of virus-associated kinase in a total volume of $30 \mu \mathrm{l}$. Purified CaMV particles and protein CP 1 to 265 alone were used as controls. After $3 \mathrm{~h}$ at $37^{\circ} \mathrm{C}$, the reactions were stopped by the addition of $10 \mu \mathrm{l}$ of SDS-PAGE sample loading buffer and boiling for $5 \mathrm{~min}$. Phosphorylated proteins were separated by SDS-PAGE using $12 \%$ polyacrylamide gels. The gels were dried onto Whatman paper before exposing to the storage phosphor screens (Molecular Dynamics, Synnwall, CA, U.S.A.). A Typhoon Imager was used to read the signal of the radioactive protein bands and the program ImageQuant software (Molecular Dynamics) for their analysis. The value (percentage of phosphor) corresponding to each band was taken and exported to Excel. Net phosphorylation values were ob- 
tained by drawing a rectangle over each single band, considering the WT protein as the reference.

\section{Phosphorylation with human CKII.}

Recombinant human CKII (New England Biolabs) was used to test whether our recombinant proteins were phosphorylated by CKII activity. Reactions were performed with each of the mutant and WT CP proteins in $1 \times$ CKII reaction buffer $(20$ $\mathrm{mM}$ Tris- $\mathrm{HCl}, 50 \mathrm{mM} \mathrm{KCl}$, and $10 \mathrm{mM} \mathrm{MgCl}_{2}, \mathrm{pH} \mathrm{7.5}$, at $\left.25^{\circ} \mathrm{C}\right)$ with $200 \mu \mathrm{M}$ ATP, $2.5 \mu \mathrm{Ci}$ of $\left[\gamma_{-}{ }^{32} \mathrm{P}\right] \mathrm{ATP}(3,000$ $\mathrm{Ci} / \mathrm{mmol}$ ), and 250 units of human CKII for $1 \mathrm{~h}$ at $30^{\circ} \mathrm{C}$. CKII enzyme was used as control. Reactions were stopped by addition of sample buffer and boiling for $5 \mathrm{~min}$. Proteins were separated by SDS-PAGE using $12 \%$ polyacrylamide gels. The gels were dried onto Whatman paper and phosphorylated bands were detected and quantified as above for virus-associated kinase assays.

\section{Protein detection or immunodetection.}

Proteins samples (loading control) resolved on 12\% SDSPAGE gels were detected by staining with SYPRO Orange (Molecular Probes) using a 1/5000 dilution of the dye stock in $7.5 \%$ acetic acid for $1 \mathrm{~h}$. Gels were destained in a $7.5 \%$ acetic acid solution. The Typhoon setting was $630 \mathrm{~nm}$ excitation. Immunodetection of protein was done according to a Western transfer protocol with detection using an ECL system.

\section{Investigation of CaMV accumulation by DNA dot blot hybridization.}

Accumulation of CaMV mutants in turnip (B. rapa) was tested 28 days postinoculation by DNA dot blot hybridization with a DNA probe. $B$. rapa plants were inoculated at the threeleaf stage using $0.1 \mu \mathrm{g}$ of circularized WT, S66,68,72A, and S66,68,72D and also inoculated with $1 \mu \mathrm{g}$ of C-terminal mutants 7SA, 3TA, and 7SA + 3TA DNA using particle bombardment. Twenty-eight days postinoculation, plant tissues were ground in $1 \mathrm{ml}$ of Tris-HCl, $\mathrm{pH} 8$, and $1 \mathrm{mM}$ EDTA per $2 \mathrm{~g}$ of fresh weight and diluted (1:2 to $1: 8)$. Then. $50 \mu \mathrm{l}$ of the crude extracts were spotted onto nitrocellulose membrane and air dried. A radiolabeled DNA probe was prepared by using three primers specific for the CaMV genome (XhoI, 9485New, and 9483). Hybridization and washing were performed following standard protocols (Sambrook et al. 1989).

\section{Statistical analysis.}

All statistical analyses were performed using GraphPad Software (San Diego, CA, U.S.A.). Statistical comparisons were made by analysis of variance for the percentage of phosphorylation. Dunnett's multiple comparison test was used to compare data with control $\mathrm{CP}^{*}$ or CP 99-489 for each phosphorylation assay at a confidence interval of $95 \%$.

\section{ACKNOWLEDGMENTS}

This study was supported by a grant form the "Conseil de Recherche en Sciences Naturelles et en Genie du Canada" (CRSNG). We thank C. Deffrasnes and M. Vaillancourt for fruitful discussions and assistance, $\mathrm{T}$.
Hohn for the kind gift of the Cabb-B-S clone; and H. Rothnie for editing and critical reading of the manuscript.

\section{LITERATURE CITED}

Champagne, J., Benhamou, N., and Leclerc, D. 2004. Localization of the $\mathrm{N}$-terminal domain of Cauliflower mosaic virus coat protein precursor. Virology 324:257-262.

Chapdelaine, Y., and Hohn, T. 1998. The Cauliflower mosaic virus capsid protein: Assembly and nucleic acid binding in vitro. Virus Genes 17:139-150.

Chapdelaine, Y., Kirk, D., Karsies, A., Hohn, T., and Leclerc, D. 2002. Mutation of capsid protein phosphorylation sites abolishes Cauliflower mosaic virus infectivity. J. Virol. 76:11748-11752.

Geldreich, A., Albrecht, H., and Lebeurier, G. 1988. A 37 kilodalton protein kinase associated with Cauliflower mosaic virus. Virus Genes 2:313-322.

Guerra-Peraza, O., de Tapia, M., Hohn, T., and Hemmings-Mieszczak, M. 2000. Interaction of Cauliflower mosaic virus coat protein with the pregenomic RNA leader. J. Virol. 74:2067-2072.

Hohn, T., and Fütterer, J. 1997. The proteins and functions of plants pararetroviruses: Knows and unknowns. Crit. Rev. Plant Sci. 16:133-161.

Hull, R., and Shepherd, R. 1976. The coat protein of Cauliflower mosaic virus. Virology 70:217-220.

Karsies, A., Hohn, T., and Leclerc, D. 2001. Degradation signals within both terminal domains of the Cauliflower mosaic virus capsid protein precursor. Plant J. 27:335-343.

Karsies, A., Merkle, T., Szurek, B., Bonas, U., Hohn, T., and Leclerc, D. 2002. Regulated nuclear targeting of Cauliflower mosaic virus. J. Gen. Virol. 83:1783-1790.

Leclerc, D., Chapdelaine, Y., and Hohn, T. 1999. Nuclear targeting of the Cauliflower mosaic virus coat protein. J. Virol. 73:553-560.

Martinez-Izquierdo, J., and Hohn, T. 1987. Cauliflower mosaic virus coat protein is phosphorylated in vitro by a virion associated protein kinase. Proc. Natl. Acad. Sci. U.S.A. 84:1824-1828.

Meggio, F., and Pinna, L. A. 2003. One-thousand-and-one substrates of protein kinase CK2? FASEB (Fed. Am. Soc. Exp. Biol.) J. 17:349-368.

Menissier-de Murcia, J., Geldreich, A., and Lebeurier, G. 1986. Evidence for a protein kinase activity associated with purified particles of Cauliflower mosaic virus. J. Gen. Virol. 67:1887-1891.

Naso, R. B., Karshin, W. L., Wu, Y. H., and Arlinghaus, R. B. 1979. Characterization of 40,000- and 25,000-dalton intermediate precursors to Rauscher murine leukemia virus gag gene products. J. Virol. 32:187-198.

Rothnie, H. M., Chapdelaine, Y., and Hohn, T. 1994. Pararetroviruses and retroviruses: A comparative review of viral structure and gene expression strategies. Adv. Virus Res. 44:1-67.

Rue, S. M., Roos, J. W., Tarwater, P. M., Clements, J. E., and Barber, S. A. 2005. Phosphorylation and proteolytic cleavage of Gag proteins in budded Simian immunodeficiency virus. J. Virol. 79:2484-2492.

Sambrook, J., Fritsch, E. F., and Maniatis, T. 1989. Molecular Cloning: A Laboratory Manual. Cold Spring Harbor Laboratory Press, Cold Spring Harbor, NY, U.S.A.

Schagger, H., and von Jagow, G. 1987. Tricine-sodium dodecyl sulfatepolyacrylamide gel electrophoresis for separation of protein in the range from 1 to $100 \mathrm{kDa}$. Anal. Biochem. 166:368-379.

Torruella, M., Gordon., K., and Hohn, T. 1989. Cauliflower mosaic virus produces an aspartic proteinase to cleave its polyproteins. EMBO (Eur. Mol. Biol. Organ.) J. 8:2819-2825.

Yoshinaka, Y., and Luftig, R. B. 1982. In vitro phosphorylation of murine leukemia virus proteins: Specific phosphorylation of Pr65gag, the precursor of the internal core antigens. Virology 116:181-195.

\section{AUTHOR-RECOMMENDED INTERNET RESOURCE}

Swiss Institute of Bioinformatics ExPASy (Expert Protein Analysis System) proteomics server: www.Expasy.ch 